\title{
膀胱上皮内癌の進展様式
}

\author{
信州大学医学部泌尿器科（主任：小川秋實教授） \\ 岡根谷利一 井門 買介 小川 秋實
}

\section{THE PROGRESS PATTERN OF CARCINOMA IN SITU OF THE URINARY BLADDER}

\author{
Toshikazu Okaneya, Shinsuke Ikado and Akimi Ogawa \\ Department of Urology, Shinshu University School of Medicine \\ (Director: Prof. A. Ogawa)
}

Forty patients with carcinoma in situ of the bladder were reviewed. They included 15 patients with primary carcinoma in situ, 8 with secondary carcinoma in situ and 17 with concurrent carcinoma in situ. Twenty-one $(66 \%)$ of 32 patients with primary or concurrent carcinoma in situ complained of urinary frequency and pain on urination, whereas no patients with secondary carcinoma in situ complained of such symptoms. Nearly all patients with concurrent or secondary carcinoma in situ had gross hematuria, whereas only $7(47 \%)$ of 15 patients with primary carcinoma in situ had gross hematuria. Two patients without any symptoms were diagnosed by incidental positive urinary cytology. Concurrent carcinoma in situ was always associated with multiple papillary tumor. Dominant grade of the papillary tumor was classified as grade 3 in 11 patients and as grade 2 in 6 . The simultaneous presence of carcinoma in situ of the urethra was found in $13(46 \%)$ patients and those of the ureter in $17(74 \%)$. Fourteen patients (35\%) with carcinoma in situ developed an invasive carcinoma. Of these, $4(10 \%)$ died of cancer. Bacillus calmette-guerin instillation was effective in 13 of 15 patients (87\%). These results indicate that carcinoma in situ of the bladder may develop an invasive cancer, may remain in the epithelia, or may be associated with multiple superficial tumor. It should be emphasized that patients with multiple superficial bladder tumor may be associated with carcinoma in situ even if the superficial tumors are of low grade and urine cytology is negative.

Key words: carcinoma in situ, superficial bladder tumor, invasive bladder tumor

要旨：40例の膀胱上皮内癌症例の経過を解析した。内訳は原発性膀朕上皮内癌15例，続発性膀胱上皮内 癌 8 例, 随伴性膀胱上皮内癌17例であった。 頻尿, 排尿時痛などの膀脂刺激症状は, 原発性と随伴性の 上皮内癌32例中21例（66\%）にみられたが, 続発性上皮内癌ではみられなかった. 肉眼的血尿は随伴性 と続発性の上皮内癌のほ注全例にみられたが，原発性上皮内癌では15例中 7 例 (47\%)にのみみられた。 全く無症状で尿細胞診によって偶然発見された上皮内癌が 2 例あった。随伴性膀胱上皮内癌を伴う乳頭 状腫瘍は17例全例で複数個みられ, その最も優位な組織学的異型度は grade $3 か ゙ 11$ 例, grade 2 が 6 例で

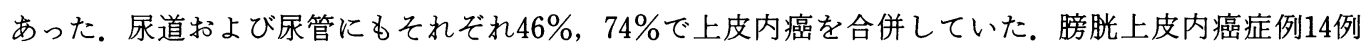
（35\%）が経過中に浸潤性腫瘍へ進行し，4例（10\%）が癌死した. BCG 膀腅内注入療法は15例中13例 （87\%）が有効であった，原発性膀胱上皮内癌のなかには，ある時急激に浸潤性に増殖を始めるものと， 上皮内に留まり増殖性变化を示さないもの以外に, 表在性乳頭状腫瘍を頻回にしかも多発性に再発を繰 り返すが，膀胼刺激症状や尿細胞診陽性という，いわゆる上皮内癌に特徵的な所見に比較的乏しく, 当 面浸潤性増殖をしないものがあると思われる. 短期間に多発性表在性乳頭状腫瘍の再発を繰り返す例に ついては，たとえ尿細胞診が陰性であったり組織学的異型度の低い腫瘍であっても, 積極的に膀羘上皮 内癌を疑って膀胀粘膜生検を行らべきである.

キーワード：膀胱上皮内癌, 表在性膀胱腫瘍, 浸潤性膀胱腫瘍 


\section{緒}

最近膀胱上皮内癌 (CIS) の症例が増加している。そ の理由は拉そらく尿細胞診検査がょり一般的な検査法 として普及したために，それによって CIS の疑いをも たれることが多くなったこと, それに, 泌尿器科医が CIS といら疾患概念を念頭に扣いて診療するように なったことであろう。しかし, 我々の経験では, 乳頭 状膀胱腫瘍が合併している例では膀脱無作為生検を行 わないために見落されている例が意外に多い。また， この様な合併例が CIS の発育進展のどのような過程 にあるのか，あるいは乳頭状腫瘍といわゆる上皮内癌 とは全く別の発育様式を示寸病変と考えるべきなのか といったことも明確にわかっていない。

自験例を解析して臨床経過と病理組織所見について 検討することにより，CIS の自然史を推論することを 試みた。

\section{対象および方法}

信州大学医学部泌尿器科で1978年 4 月から 1990 年 6 月までの 12 年 3 力月間に膀胱上皮内癌 (CIS) と診断さ れた症例は40例であり, 平均65.2歳であった。これは 同期間の膀胱腫瘍新患 388 例，平均 66.8 歳の $10.3 \%$ で あった。内訳は男性 31 例 (78\%)，女性 9 例 (22\%) で あった。これらの手術標本を日本泌尿器科学会の膀胼 癌取扱い規約を参考にして検討したが，本研究での上 皮内癌の定義は, grade 3の非隆起性移行上皮癌とし, grade 2 以下の細胞異型を呈する例は, dysplasia とし て対象から除外した。また，筋層に浸潤する膀胱腫瘍 （pT2以上）を合併している症例は除外したが，それら の内, 病理組織の再検討により, それ以前の手術標本 にCIS のあったことが判明した 6 例は対象に含めた。 粘膜固有層に直径約 $5 \mathrm{~mm}$ 以内の微小浸潤癌を合併し ている例は，CIS の自然史を考える上で重要と思われ たので対象に含めた。

CIS の分類は, 表在性乳頭状膀胱腫瘍の合併がなく, 膀胼腫瘍の既往もない例を原発性 CIS, 表在性乳頭状 膀胼腫瘍の既往があり，その後に腫瘍の証明されない 期間を経て CIS が出現した例を続発性 CIS, 膀胼腫瘍 の既往の有無に関わらず，乳頭状腫崵に合併して CIS がみられる場合を随伴性 CIS と分類した。病理組織診 断は 2 名の病理医により行った。

これらの症例について臨床経過, および病理組織学 的に尿管 CIS 括よび尿道 CIS の合併の有無, 膀胱壁内 の脈管侵襲の有無について検討した。

\section{結果}

症例の内訳を表 1 に示す。原発性 CIS 15 例のらち 10 例 (67\%) は最近 3 年間に診断された症例であった.

症状の初発あるいはCIS が初めて疑われてから確 定診断がなされるまでの期間は最短 1 力月, 最長 102 力 月, 平均 19.2 力 月であった。 この期間は原発性 CIS で は $1 \sim 72$ 力 (平均20.5力月), 続発性 CIS では 10 102 月月 (平均 35.1 力), 随伴性 CIS では $1 \sim 48$ カ月 (平均11.1カ月) であった。続発性 CIS の 8 例中, 5 例では過去に 1 年に 3 回以上の乳頭状膀胖腫瘍の再 発がみられていた。

臨床症状として頻尿, 排尿時痛などの膀胱刺激症状 と血尿の発現率を表 2 に示す。膀脱刺激症状は原発性 CIS と随伴性 CIS の過半数にみられたが, 続発性 CIS では膀胱刺激症状を示したものはなかった。肉眼的血 尿は，随伴性と続発性 CIS のほ注全例にみられたが, 原発性 CIS では半数弱にみられたのみであった。全く 無症状で尿細胞診によって偶然発見されたCIS が 2 例あった ${ }^{11}$. 各分類での発現率は表 2 に示す。

病理組織学的には, 膀胱粘膜固有層の微小浸潤癌の 病巣が 8 例 (20\%) でみられた。膀脱刺激症状の有無 と微小浸潤癌の有無とには, 統計学的に相関はなかっ た（表 3 ). 膀胖粘膜固有層のリンパ管侵襲は 7 例 (17.5\%)にみられたが，これらはいずれも随伴性 CIS 症例であった。随伴性 CIS を伴う隆起性腫瘍は17例全 例で複数個みられ，その最も優位な組織学的異型度は

表 1 CIS 症例（信州大学, 1978 1990)

\begin{tabular}{c|c|c|c}
\hline & 例数 & 平均年齢 & 診断までの期間 (月) \\
\hline 原発性 & 15 & 65.3 & 20.5 \\
続発性 & 8 & 62.6 & 35.1 \\
随伴性 & 17 & 66.4 & 11.1 \\
\hline
\end{tabular}

表 2 CIS の症状発現率

\begin{tabular}{l|c|c|c}
\hline & 原発性 (15例) & 続発性（8 例) & 随伴性 (17例) \\
\hline 膀䏚刺激症状 & $73 \%$ & $0 \%$ & $59 \%$ \\
肉眼的血尿 & $47 \%$ & $100 \%$ & $94 \%$ \\
\hline
\end{tabular}

表 3 微小漫潤癌の有無と膀胼刺激症状

\begin{tabular}{|c|c|c|}
\hline & 溦小浸潤癌（+） & 擞小漫潤癌 (一) \\
\hline 膀肶刺激症状 (+) & 5 & 11 \\
\hline 膀胱刺激症状 (一) & 3 & 15 \\
\hline
\end{tabular}


grade 3 が11例, grade 2 が 6 例であった。 この内 3 例 では筋層に浸潤している部分があり，それ以前の手術 標本を再検討したところCIS の存在を初めて確認し たため，CIS が浸潤癌に進展したものと考えた。

また続発性 CIS に先行した表在性乳頭状腫瘍の grade は G3が 2 例，G2が 5 例，G1が 1 例であった。

自験40例全例で膀脱生検を行って抢り，らち20例で は最終的に膀胱全摘除術を行ったが，これら40例のら ち，生検打よび擦過細胞診により病理学的に尿道打よ び尿管の検索を行ったのはそれぞれ28例, 23例であり， このらち尿道 CIS 拈よび尿管 CIS がそれぞれ13例 (46\%)，17例（74\%）に合併していた（表 4)。尿道 dysplasia，尿管 dysplasia がそれぞれ 4 例，1例にみ られた。尿管 CIS の病変の多くは壁内尿管にとどまっ ていた。隆起性の尿管腫場の合併も 4 例（10\%）に久 られ，この 4 例はいずれもCIS と同時に診断されてお り，3 例は下部尿管腫瘍であったが，1例は尿管全長 にわたる多発腫瘍であった．前立腺導管の検索を行な い壳た 25 例中 5 例（20\%）でCIS がみられた。

最終治療を行う直前の膀胱上皮内癌の状態は表 5 に 示す。14例（35\%）で浸潤性腫瘍への進展が確認され た.

治療法として初期は thiotepa などの膀胼内注入療 法を行ったが，最終的に膀羘全摘手術を行ったのは 20 例，尿管腫場の合併に対して腎尿管全摘を施行したの は 4 例であった。最近の 17 例では BCG 膀脱内注入療 法を行った. BCG 膀脱内注入療法の終了した15例の内

表 4 尿管, 尿道, 前立腺導管上皮内癌の合併

\begin{tabular}{c|c|c|c}
\hline & 尿道（\%) & 尿管（\%) & 前立腺導管（\%) \\
\hline 原発性 & $8 / 10$ & $7 / 8$ & $2 / 8$ \\
続発性 & $2 / 6$ & $3 / 6$ & $1 / 6$ \\
随伴性 & $3 / 12$ & $7 / 9$ & $2 / 11$ \\
\hline 合計 & $13 / 28(46 \%)$ & $17 / 23(74 \%)$ & $5 / 25(20 \%)$ \\
\hline
\end{tabular}

表 5 膀胱上皮内癌症例の経過

\begin{tabular}{l|c|c|c}
\hline & $\begin{array}{c}\text { 原発性 } \\
(15 \text { 例 })\end{array}$ & $\begin{array}{c}\text { 続発性 } \\
(8 \text { 例 })\end{array}$ & $\begin{array}{c}\text { 随伴性 } \\
(17 \text { 例 })\end{array}$ \\
\hline 浸潤性腫瘍へ進展 (14例) & 3 & 2 & 9 \\
表在性腫瘍を合併 (16例) & 4 & 4 & 6 \\
膀胱上皮内癌のみ (9 例) & 8 & 1 & 0 \\
その他 ( 3 例)* & 0 & 1 & 2 \\
\hline
\end{tabular}

*不明 1 例, 温熱療法および BCG 膀脂内注入療法に上る萎 縮膀胱 2 例
13例（87\%）で有効であった。そのらち最終的に全摘 したものが 4 例あった 2 .

転帰の明らかな38例のうち，上皮内癌の浸潤による 癌死は 4 例 (11\%) であった。そのらち原発性あるい は続発性 CIS 症例は 2 例であり, この 2 例の症状の初 発から診断確定までは102カ月および72カ月がかかっ ていた。

CIS が急激に浸潤をきたした 1 例，および一見表在 性乳頭状腫瘍の形態を示した 1 例を示す。

症例 $1 ： 51$ 歳男性. 1981年11月頃から頻尿，排尿時 痛が出現，1982年 6 月から時々肉眼的血尿がみられ， 尿細胞診では class IV， class V であったが，膀胱鏡 検查では異常がなかった。その後 5 回の膀脱生検では 粘膜の永離が著明であったが悪性細胞は証明されな かった。1983年12月に G2 扮よび G3の多発性乳頭状腫 瘍が出現, 急激に増大し, 粘膜の発赤も著明となり, 水腎が出現した。膀胱全摘除術を行ったが病理組織は 移行上皮癌 G3 pTis 拈よび移行上皮癌 G3, pT $1 b$,

INF $\beta$, ly1であった。

症例 $2 ： 21$ 歳男性. 1983年（16歳時）秋から時々肉 眼的血尿が出現した。1985年 2 月以後，表在性乳頭状 膀腃腫瘍の診断で経尿道的腫瘍切除術を 7 回, テスパ ミン膀脱内注入療法, 膀胼部ライナック照射を行った。 病理組織は全て移行上皮癌 G1であった。 その後萎縮膀 胱となっていたが，1988年突然肺転移が出現，肺切除 術にて移行上皮癌 G1の診断であった. 膀胼無作為生検 で G1腫瘍の再発が認められたため膀胱全摘除術を 行った。摘出標本の検索により G3上皮内癌が発見され た。

\section{考察}

CIS の自然史を考学る上で重要と思われる事実は次 のことである。自験例のうち, 臨床的に原発性 CIS と 診断された 15 例中 5 例に病理組織学的には既に微小浸 潤癌が認められたこと, 原発性 CIS の状態からある時 期に多発性乳頭状腫瘍が急激に増殖し, 同時に微小浸 潤癌と壁内リンパ管侵襲も見られるようになった 1 例 があること, 66 カ月の経過中に G1の表在性乳頭状腫瘍 の再発が何回もみられ，経過中に肺転移をきたした 1 例で CIS が証明されたこと,および続発性 CIS 症例 8 例中 5 例で過去に頻回に表在性腫瘍の再発を繰り返し たことである。

従来, 膀胼上皮内癌は浸潤性膀胱癌の初期病変と考 光て浸潤性膀胱癌と同様の治療方針をとることが多 かったが，上皮内癌のまま長期間経過するもののある 
図 1 膀胱上皮内癌は, (1)浸潤性腫瘍への進展, (2)上 皮内に留末る, 以外に, (3)多発性乳頭状（表在性） 腫瘍の形態に進展するものがある。
(1)

(2)
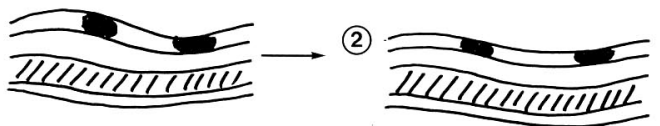

(3)

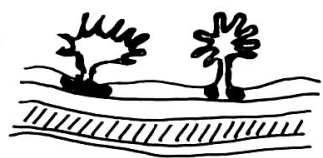

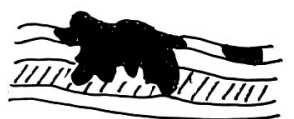

図 2 随伴性 CIS 症例の病理組織. 表在性乳頭状腫瘍 とCIS が接している.図 1 の(3)に該当する(H.E. 染 色 $\times 100$ ).

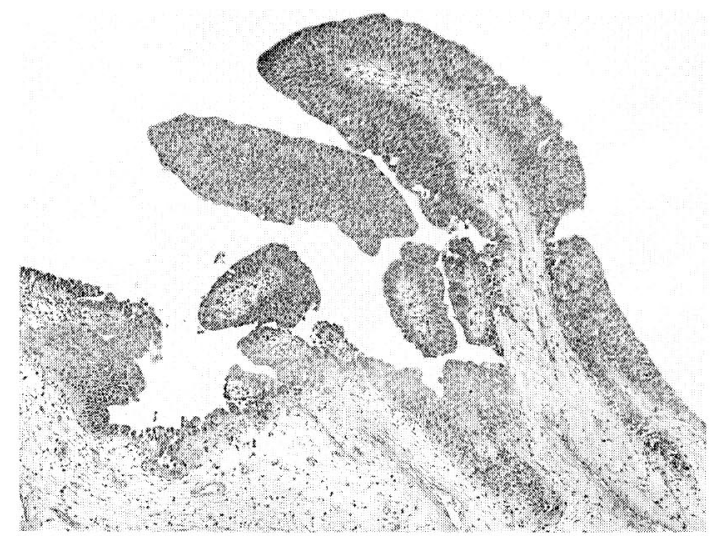

ことが知られてきた。また，膀脱上皮内癌の特徵とし て膀脱刺激症状の強いことが強調されてきた。自験例 の結果からは，原発性 CISのなかに，ある時点から急 激に浸潤性に増殖を始めるものと, 上皮内に留をり増 殖性変化を示さないもの以外に, 表在性乳頭状腫瘍を 頻回にしかも多発性に再発を繰り返寸が，膀胧刺激症 状の発現が少なく，当面浸潤性増殖をしないものがあ ると思示机る(図 1 - 3 ). 従来 CIS は, その進展速度 が速いものと比較的緩徐なものがあることが強調され てきたが，その過程で乳頭状膀朕腫瘍の形態をとる場 合があることは姫とんど論じられていない。

Kakizoe らは多発性表在性腫瘍の膀脱全摘例に対 し step-sectionによるマッピングを行い, 乳頭状腫瘍 がCISから発生する場合のあることを示している3).
図 3 㘠 2 の上皮内癌の部分の拡大 (H.E. 染色 $\times$ 400).

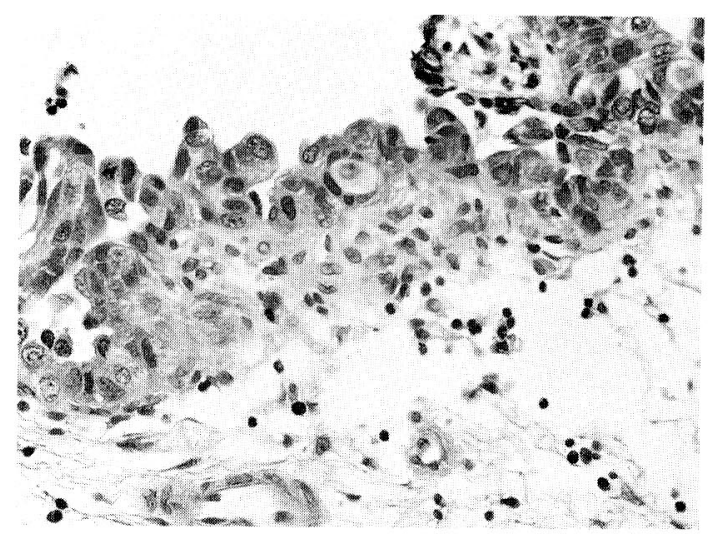

Melicow ${ }^{4)}$ 赤座ら ${ }^{5}$ の言うように, CIS と乳頭状腫瘍 が全く別々に共存する可能性も可定できないが，CIS に合併する乳頭状腫瘍が，通常多発性であること，組 織学的異型度が高いものが多い点がCISを合併しな い乳頭状腫瘍と異なることなど，単なる偶然での共存 説ではやや不自然な点がある.

自験例の経過を分析すると, CIS に合併する表在性 乳頭状膀脱腫瘍の多くは, 上皮内癌の発育進展の一つ の様式と説明するのが適切と思われる。この考点方に 従って, 多発性乳頭状腫瘍の頻回再発例に対しては積 極的に無作為粘膜生検を行った結果, CIS 40例のらち 19例が最近 3 年間に診断された症例であった。

CIS は尿細胞診が陽性に出やすいことが強調されて いるが，比較的緩徐に表在性乳頭状腫瘍の再発を繰り 返すタイプでは, 経過中の細胞診の陽性率は比較的低 く，その症例の膀脱全摘標本でも CIS の占める範囲は 比較的狭い印象であった。このことからは, Kakizoe ${ }^{3)}$, Farrow ら は, CIS の占める範囲之癌細胞の永離傾向に様々な程 度のものがあると思われる。従来, CIS では膀胱刺激症 状の出現しやすいことが強調されているが, 自験例の 結果からは膀胱刺激症状, 肉眼的血尿とも呈さない症 例があることに留意すべきである。

続発性 CIS 症例は, おそらく最初の時点で膀胱生検 を入念に行っていればCISがみつかっていたと思わ れ, CIS の占める範囲が比較的狭く, しか子細胞剥離傾 向が弱いために細胞診が陰性化し, 腫瘍が一旦消失し たように文たのであらう。すなわち，続発性 CIS と 称されるものには, 表在性乳頭状腫瘍を合併する CIS 
の一過程にあるものが少なからず含まれていると思わ れる。

しかし，上皮内癌を合併していない表在性あるいは 浸潤性腫瘍の方がむしろ多く7), その起源は CIS 以外 に求めるべきである。 また，浸潤性腫瘍に合併してい る上皮内癌には, “上皮内進展”と解釈すべき症例もあ $ろ^{8)}$.

随伴性 CIS の特徵として, 臨木的には短期間に多発 性乳頭状腫瘍の再発を繰り返し，その間尿細胞診が陽 性にでやすいこと，また病理組織学的には合併表在性 腫瘍は G3，G2の他に G1もみられることがあげられ る.自験例では随伴性 CIS の全てが G3または G2の表 在性腫瘍との合併であり, Prout $5^{9)}$ の報告でも組織異 型の軽度な腫瘍との合併は84例中 2 例と少なく, 関根 $5^{10)}$ 女同様の結果を示している. 一方, VincenteRodriguez $ら^{11)}$ は全ての膀胱腫瘍患者に無作為膀胱生 検を施行し, $21.88 \%$ 症例で CIS が合併しており, G1 腫瘍でも5.26\%で CIS が合併していたと報告してい るが, 自験例でも続発性 CIS の 1 例（症例 2 ）に G1腫 瘍の合併がみられたのと一致している.このことから, たとえ G1腫瘍で細胞診陰性であってもCIS の存在を 疑って積極的に膀胼粘膜生検を施行すべきであろう.

CIS は $4 \sim 6$ 年以内に $50 \%$ が，また 10 年以内に $80 \%$ が浸潤性腫瘍に進展する ${ }^{12)}$ という意見，あるいは 26〜33カ月の間 ${ }^{13)}$ ，また18〜 77カ月の間 ${ }^{14)} に$ 浸潤する とする意見があるが，自験例でも 1 〜 102 カ月の間に $35 \%$ 症例で浸潤が生じていた，従って，抗癌剂や BCG の膀胼内注入療法などで保存的に経過をみる場 合でも腫瘍が完全に消失しない限り 2 〜 年を限度と 考えるべきであり，浸潤の始まる時を見逃さないよう にしなければならない. 自験例の結果から, 膀胱刺激 症状の有無はその指標にならないと思われる。

膀胱上皮内癌がいずれの進展様式をとるかはその初 期段階では予測し難い。

尿道扎よび尿管の上皮内癌合併は，自験例ではそれ ぞれ46\%，74\%にみられたが，これまでにも Farrow

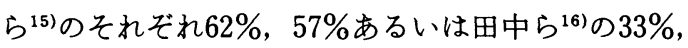
$50 \%$ といった報告がある，前立腺導管にも20\%の例で 上皮内癌がみられたことからも，治療法を決定する際 に病変のひろがりを正確に把握しておくことが肝要で あろ5。また, CIS 周囲には少なからず dysplasia がみ られるが6), 治療の観点からはCIS と同様に扱らべき であろう。

本論文の要旨は, 第55回日本泌尿器科学会東部総会にお
いて発表した。

文 献

1）小川秋實, 岡根谷利一：老年者の膀脂腫瘍. 老化と 疾患，3，757-761，1990。

2) 岡根谷利一, 井門恉介, 村田 靖, 庭川 要, 水沢 弘哉, 山口建二, 山下俊郎, 小川秋實 : 膀胱腫瘍に 対する BCG 膀胱内注入療法：40mg10回注入の成 績. 臨泌, 2, 129-132, 1991.

3) Kakizoe, T., Matsumoto, K., Nishio, Y. and Kishi, K.: Analysis of 90 stepsectioned cystectomized specimens of bladder cancer. J. Urol., 131,. 467-472, 1984.

4) Melicow, M.M.: Histological study of vesical urothelium intervening between gross neoplasms in total cystectomy. J. Urol., 68, 261-279, 1952.

5）赤座英之, 新島端夫：原発性膀胼上皮内癌の臨床 的観察。日泌尿会誌，77，1296-1299，1986.

6) Farrow, G.M., Utz, D.C., Rife, C.C. and Greene, L.F. : Clinical observations on sixty-nine cases of in situ carcinoma of the urinary bladder. Cancer Res., 37, 2794-2798, 1977.

7) Soto, E.A., Friedell, G.H. and Tiltman, A.J. : Bladder cancer as seen in giant histologic sections. Cancer, 39, 447-455, 1977.

8）瀬戸輝一, 松本恵一：膀胼上皮内癌（Carcinoma in situ）の病理. 臨泌, 31, 195-206, 1977.

9) Prout, G.R., Uriffin, P.P., Daly, J.J. and Heney, N.M. : Carcinoma in situ of the urinary bladder with and without associated vesical neoplasms. Cancer, 52, 524-532, 1983.

10）関根英明：膀胼癌に伴 5 dysplasia 病変の研究. 一Giant sectionにおける病理組織所見とそれに 対応する尿細胞診所見一。日泌尿会誌, 80 , 545-554, 1989.

11) Vincente-Rodriguez, J., Chechile, G., Algaba, F. and Amaral, J. Jr.: Value of random endoscopic biopsy in the diagnosis of bladder carcinoma in situ. Eur. Urol., 13, 150-152, 1987.

12) Tannenbaum, M. and Romas, N.A.: The pathobiology of early urothelial cancer. in Genitourinary Cancer. Edited by Skinner, D.G. and deKernion, J.B., p. 55, Saunders Co., Philadelphia, 1978.

13) Melamed, M.R., Vousta, N.G. and Grabstald, H. : Natural history and clinical behavior of in situ carcinoma of the human urinary bladder. Cancer, 17, 1533-1545, 1964.

14) Koss, L.G., Melamed, M.R. and Kelly, R.E. : Further cytologic and histologic studies of bladder lesions in workers exposed to paraaminodiphenyl. Progress report. J. Natl. Cancer 
Inst., 43, 233-243, 1969.

15) Farrow, G.M., Utz, D.C. and Rife, C.C.: Morphological and clinical observations of patients with early bladder cancer treated with total cystectomy.CancerRes.,36, 2495-2501， 1976.
16）田中正敏, 藤本 博, 小川秋實, 石井善一郎： 原発性膀脱上皮内癌の病理学的検討. 臨泌, 41, 35-38, 1987.

（1991年 5 月 2 日受理） 